\title{
SMR
}

\section{Characterization of the complete mitochondrial genome and phylogenetic relationships of the three-spot swimming crab (Portunus sanguinolentus)}

H.Y. Ma ${ }^{1,2}$, C.Y. Ma ${ }^{1}$, J.J. Zhu ${ }^{3}$, G.J. Ren ${ }^{1}$, W. Wang ${ }^{1}$, W. Chen ${ }^{1}$, J.X. Lu ${ }^{1}$ and L.B. $\mathrm{Ma}^{1}$

${ }^{1}$ East China Sea Fisheries Research Institute, Chinese Academy of Fishery Sciences, Shanghai, China

${ }^{2}$ Guandong Provincial Key Laboratory of Marine Biology, Shantou University, Shantou, China

${ }^{3}$ Guangxi Academy of Fishery Sciences, Nanning, China

Corresponding authors: H.Y. Ma / L.B. Ma

E-mail: mahongyuhome@163.com / malingbo@vip.sina.com

Genet. Mol. Res. 15 (3): gmr. 15038580

Received February 29, 2016

Accepted May 17, 2016

Published August 29, 2016

DOI http://dx.doi.org/10.4238/gmr.15038580

Copyright (C) 2016 The Authors. This is an open-access article distributed under the terms of the Creative Commons Attribution ShareAlike (CC BY-SA) 4.0 License.

ABSTRACT. In this study, we determined the whole mitochondrial genome profile of the three-spot swimming crab (Portunus sanguinolentus) and elucidated phylogenetic relationships between representative species in the order Decapoda. The mitochondrial genome was $16,024 \mathrm{bp}$ in length and consisted of 13 protein-coding genes, 22 transfer RNA genes, two ribosomal RNA genes, and a putative control region. Of the 37 genes, 23 were encoded by the heavy strand while 14 were encoded by the light strand. Four types of start codons were identified; ATG initiated nine genes, ATT initiated two genes, and 
ATC and GTG each started one gene. Nine protein-coding genes ended with a complete TAA or TAG stop codon, and four genes ended with an incomplete $\mathrm{T}$ or TA codon. Fourteen non-coding regions were found, which ranged from 1 to $34 \mathrm{bp}$ in length. Nine overlaps were observed, with lengths between 1 and $7 \mathrm{bp}$. Phylogenetic analysis suggested that $P$. sanguinolentus is genetically closest to $P$. trituberculatus and P. pelagicus. Charybdis feriata, C. japonica, and Thalamita crenata formed a single cluster, and were close to the genera Callinectes and Portunus. Therefore, the genera Charybdis and Thalamita should be classified into the subfamily Portuninae.

Key words: Portunus sanguinolentus; Mitochondrion; Gene order; Phylogenetic relationship

\section{INTRODUCTION}

The three-spot swimming crab (Portunus sanguinolentus, Herbst, 1783) is a commercially important crab species that is mainly found in the East and South China Seas, but also inhabits oceanic waters from East Africa through the Indo-Pacific region to the Hawaiian Islands (Stephenson and Campbell, 1959). Juveniles and adult males usually inhabit sandy or muddy coastal sea beds at 10 to $30 \mathrm{~m}$ in depth (Sumpton et al., 1989). In contrast, females are abundant at depths of 40 to $80 \mathrm{~m}$ (Campbell and Fielder, 1986), and in the reproductive season, berried females migrate to deeper waters for spawning.

Crab fishing in China has rapidly increased in recent decades, and there is an increasing demand for crab meat from both national and international markets. Due to over-catching and seawater deterioration, yields of this crab have substantially decreased year on year (Lee and Hsu, 2003; Yang et al., 2014). In order to assess the stock and effectively manage crab fisheries, a large amount of researches concerning the biology of P. sanguinolentus have been conducted, e.g., body size at sexual maturity, breeding season, and fecundity (Rasheed and Mustaquim, 2010). Females prefer large males to small males, and two-chela males to single-chela males (Dinakaran and Soundarapandian, 2009). To date, most studies on P. sanguinolentus have focused on morphology, and molecular techniques have been rarely applied to investigate the species' biology, evolution, and stock management.

Molecular markers are ideal genetic tools, because they can be used to investigate phylogenetic relationships, population genetic structures, and resource conservation. Mitochondrial markers are currently one of the most popular molecular markers, particularly in studies of molecular evolution, species identification, and genetic diversity (Yu et al., 2012; Sahoo et al., 2015; Korkmaz et al., 2016). The mitochondrial genome is usually a closed circular molecule, and contains 13 protein-coding genes, 22 transfer RNA (tRNA) genes, 2 ribosomal RNA (rRNA) genes, and a control region. The molecular phylogenetic position of $P$. sanguinolentus has been studied based on a single gene sequence (16S rRNA) of the mitochondrial genome, which suggested a close relationship with $P$. pelagicus and P. trituberculatus (Mantelatto et al., 2007). Although the whole mitochondrial genome of $P$. sanguinolentus has been recently reported (Meng et al., 2016a), a detailed comparative characterization of this genome with those of other crustaceans has not been conducted. In addition, several key issues, such as species identification and the taxonomic status of crab

Genetics and Molecular Research 15 (3): gmr.15038580 
species within the family Portunidae, need to be resolved.

Therefore, the aims of the present study were to determine and characterize the complete mitochondrial genome of $P$. sanguinolentus and elucidate the evolutionary status of representative species in the order Decapoda. This will improve our understanding of the species' evolutionary status, and facilitate research into its population genetic diversity and that of related crustacean species.

\section{MATERIAL AND METHODS}

\section{Sample collection and DNA preparation}

A P. sanguinolentus specimen was purchased from Qinglan Port Market, Hainan Island, China. The animal was killed by a lethal dose of tricaine mesylate. Muscle tissue was obtained and stored at $-20^{\circ} \mathrm{C}$, and genomic DNA was prepared using the traditional proteinase $\mathrm{K}$ and phenol-chloroform extraction protocol, as described by Ma et al. (2009).

\section{Polymerase chain reaction (PCR) amplification}

PCR primers were designed based on the published complete mitochondrial genome sequences of the crab species Charybdis feriata (Ma et al., 2015a), Scylla paramamosain (Ma et al., 2013), and Portunus trituberculatus (Yamauchi et al., 2003). PCR amplification was conducted in a $25-\mu \mathrm{L}$ volume that contained $0.4 \mu \mathrm{M}$ each primer, $0.2 \mathrm{mM}$ each dNTP, $1 \mathrm{X}$ PCR buffer, $1.5 \mathrm{mM} \mathrm{MgCl}, 0.75 \mathrm{U}$ Taq polymerase, and approximately $50 \mathrm{ng}$ DNA under the following conditions: one cycle of denaturation at $94^{\circ} \mathrm{C}$ for $4 \mathrm{~min} ; 35$ cycles of $30 \mathrm{~s}$ at $94^{\circ} \mathrm{C}, 50 \mathrm{~s}$ at a primer-specific annealing temperature, and $50 \mathrm{~s}$ at $72^{\circ} \mathrm{C}$. Finally, the products were extended for $7 \mathrm{~min}$ at $72^{\circ} \mathrm{C}$. The PCR products were separated on $1.0 \%$ agarose gels and directly sequenced in both directions using an ABI PRISM ${ }^{\circledR} 3730$ DNA sequencer (Applera Corp., Norwalk, CT, USA). DNA sequences were edited and assembled using the EditSeq and SeqMan (DNASTAR) software.

\section{Genome profile analysis}

The whole genome of $P$. sanguinolentus was drawn using OrganellarGenomeDRAW (http://ogdraw.mpimp-golm.mpg.de/) (Lohse et al., 2007). The genomic structure of the mitochondrion was determined based on the published mitochondrial genomes of $S$. paramamosain and $P$. trituberculatus. tRNAs were identified using the web-based tRNAscan SE 1.21 program (http://lowelab.ucsc.edu/tRNAscan-SE/) (Lowe and Eddy, 1997). The codon usage of protein-coding genes and the nucleotide composition were determined using MEGA 4.0 (Kumar et al., 2008). The whole genome was deposited into the National Center for Biotechnology Information GenBank database using the Sequin 12.30 software (http:// www.ncbi.nlm.nih.gov/Sequin/).

\section{Phylogenetic analysis}

Atotal of 22 mitochondrial genomes from the following related species were downloaded from GenBank: Thalamita crenata (LK391945), Portunus pelagicus (KT382858), C. feriata 
(KF386147), Charybdis japonica (FJ460517), Callinectes sapidus (NC_006281), Eriocheir hepuensis (NC_011598), Eriocheir japonica (NC_011597), Eriocheir sinensis (NC_006992), Litopenaeus vannamei (DQ534543), Geothelphusa dehaani (NC_007379), Fenneropenaeus chinensis (DQ518969), Pagurus longicarpus (NC_003058), Macrobrachium rosenbergii (NC_006880), Panulirus japonicus (NC_004251), Pseudocarcinus gigas (NC_006891), Marsupenaeus japonicus (NC 007010), Penaeus monodon (NC 002184), P. trituberculatus (AB093006), Scylla serrata (NC_012565), Scylla tranquebarica ( $\left.\overline{\mathrm{N} C} \_012567\right)$, Scylla olivacea (NC_012569), and S. paramamosain (JX457150). Harpiosquilla harpax (NC_006916) was used as an outgroup in the phylogenetic tree.

All 13 protein-coding genes (except ND6) were concatenated to a single multiple sequence. The multiple sequence alignment was formatted and analyzed using the RAxML webserver (http://embnet.vital-it.ch/raxml-bb/index.php) (Stamatakis et al., 2008). The evolutionary rates of the different protein-coding genes were estimated using the CAT model, and a maximum likelihood search was conducted after bootstrapping. The phylogenetic tree was drawn using FigTree v1.4.2.

\section{RESULTS AND DISCUSSION}

\section{Mitochondrial genome structure}

The mitochondrial genome of $P$. sanguinolentus (GenBank accession No. KT438509) was a circular molecule that was similar to those reported in other crab species. It was 16,024 bp in length and consisted of the following 37 genes: 13 protein-coding genes, 22 tRNA genes, 2 rRNA genes, and a control region (Figure 1).

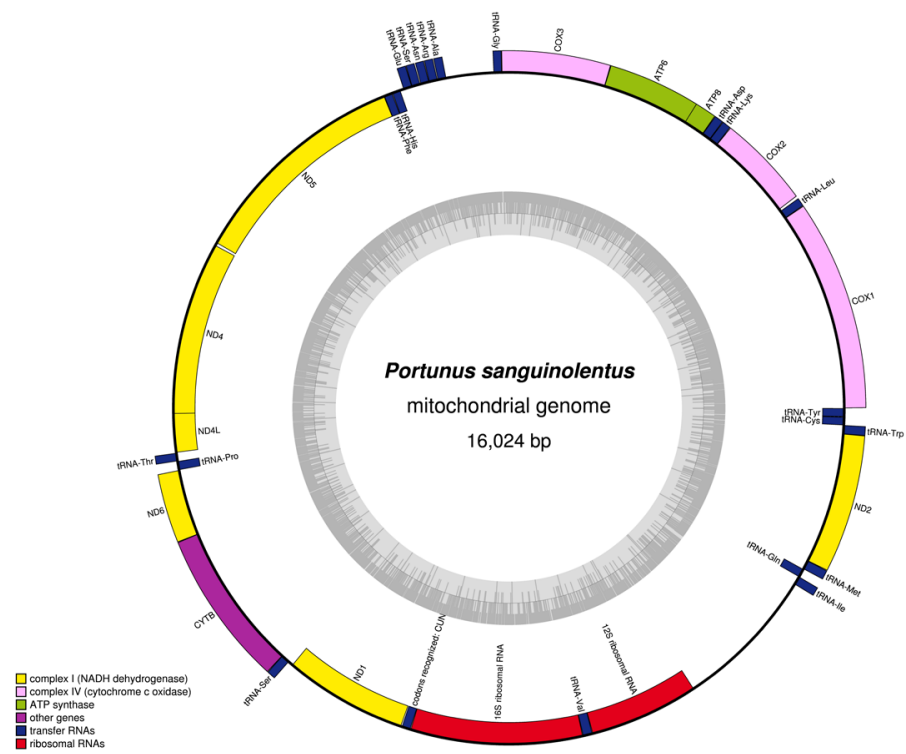

Figure 1. Complete mitochondrial genome structure of Portunus sanguinolentus. Genes located on the heavy strand are shown outside the circle and those on the light strand are shown inside the circle. The inner ring shows the GC content of the genome.

Genetics and Molecular Research 15 (3): gmr.15038580 
The gene arrangement and order were the same as those found in most metazoan species, including S. paramamosain (Ma et al., 2013), P. pelagicus (Meng et al., 2016b), and C. feriata (Ma et al., 2015a); however, they differed to those observed in the fish species Caranx tille (Ma et al., 2015b) and Macropodus opercularis (Mu et al., 2015). The genome was shorter than those in P. pelagicus (KT382858), C. sapidus (NC_006281), and E. sinensis (NC_006992), but longer than those in C. feriata (KF386147), C. japonica (FJ460517), T. crenata (NC_024438), and S. tranquebarica (NC_012567). The differences in genome length were mainly related to size variations in the control region (Table 1). The lengths of other regions of the genome were approximately equal among the above-mentioned crab species. Of the 37 genes in the genome, 23 were on the heavy strand (H-strand) and 14 were on the light strand (L-strand) (Table 2). Table 2 shows that $t R N A^{H i s}$ was between $t R N A^{\text {Glu }}$ and $t R N A^{\text {Phe }}$, which is different to that observed in most arthropods, in which $t R N A^{H i s}$ is between $N A D 4$ and NAD5. Gene rearrangements in the mitochondrial genome are relatively common events in crustacean species (Shen et al., 2007). The tandem duplication of gene regions is the most probable mechanism of mitochondrial gene rearrangement; in this case, a slipped-strand mispairing occurred first and was followed by gene deletions (Yamauchi et al., 2003).

Fourteen small, non-coding segments were identified in the genome, which ranged in size from 1 to $34 \mathrm{bp}$; most of them have been previously reported in the mitochondrial genomes of other crab species. Nine overlaps were detected among the 37 genes, which ranged from 1 to $7 \mathrm{bp}$ in length. The total lengths of the non-coding regions and overlaps were 118 and $24 \mathrm{bp}$, respectively. The overall base composition of the mitochondrial genome was $31.59 \%$ for $\mathrm{A}, 12.91 \%$ for $\mathrm{G}$, $34.01 \%$ for $\mathrm{T}$, and $21.50 \%$ for $\mathrm{C}$. The total $\mathrm{A}+\mathrm{T}$ content $(65.60 \%)$ was considerably higher than the $\mathrm{G}+\mathrm{C}$ content $(34.41 \%$ ), but is the lowest among so far reported in crab species (Table 1 ). The control region is considered to have the highest $\mathrm{A}+\mathrm{T}$ content; however, in this study, the highest $\mathrm{A}+\mathrm{T}$ content was observed in the tRNA genes $(71.41 \%)$. The control region had the lowest A $+\mathrm{T}$ content $(69.73 \%)$ of all the crab species investigated (Table 1$)$. In addition, the genome was slightly shorter than that observed in Meng's study (Meng et al., 2016a, 16,027 bp) with a total of 68 variable sites, which suggests that $P$. sanguinolentus has a moderate level of genetic diversity.

\section{Protein-coding genes}

Of the 13 protein-coding genes identified in this study, nine were encoded by the $\mathrm{H}$-strand (COI, COII, COIII, APT6, ATP8, ND2, ND3, ND6, and Cytb) and four were encoded by the L-strand (ND1, ND4, ND4L, and ND5). These genes coded 3715 amino acids, which is slightly longer than that in G. dehaani and C. sapidus but shorter than that in C. feriata and S. tranquebarica. Four types of start codons were observed in the 13 protein-coding genes; ATG initiated nine genes, ATT initiated two genes, ATC initiated one gene, and GTG initiated one gene. In addition, nine genes ended with a complete TAG or TAA stop codon and four ended with an incomplete TA- or T- stop codon. In contrast to nuclear genes, variable start codons and stop codons are often detected in mitochondrial genomes. Four types of start codons (ATT, ATG, ATA, and ACG) were found in the mitochondrial genome of Myrmeleon immanis (Yan et al., 2014), and one and two incomplete stop codons were found in the mitochondrial genomes of S. paramamosain and Lutjanus russellii, respectively (Guo et al., 2008; Ma et al., 2013). In the case of incomplete stop codons, missed nucleotides could be added by post-transcriptional polyadenylation (Ojala et al., 1981). The base composition of the 13 protein-coding genes was $30.71 \%$ for $\mathrm{A}, 13.37 \%$ for $\mathrm{G}, 33.09 \%$ for $\mathrm{T}$, and $22.81 \%$ for $\mathrm{C}$ (Table 3 ). ATP 8 had the highest $\mathrm{A}+\mathrm{T}$ content (69.14\%) and COI the lowest (59.84\%).

Genetics and Molecular Research 15 (3): gmr.15038580 


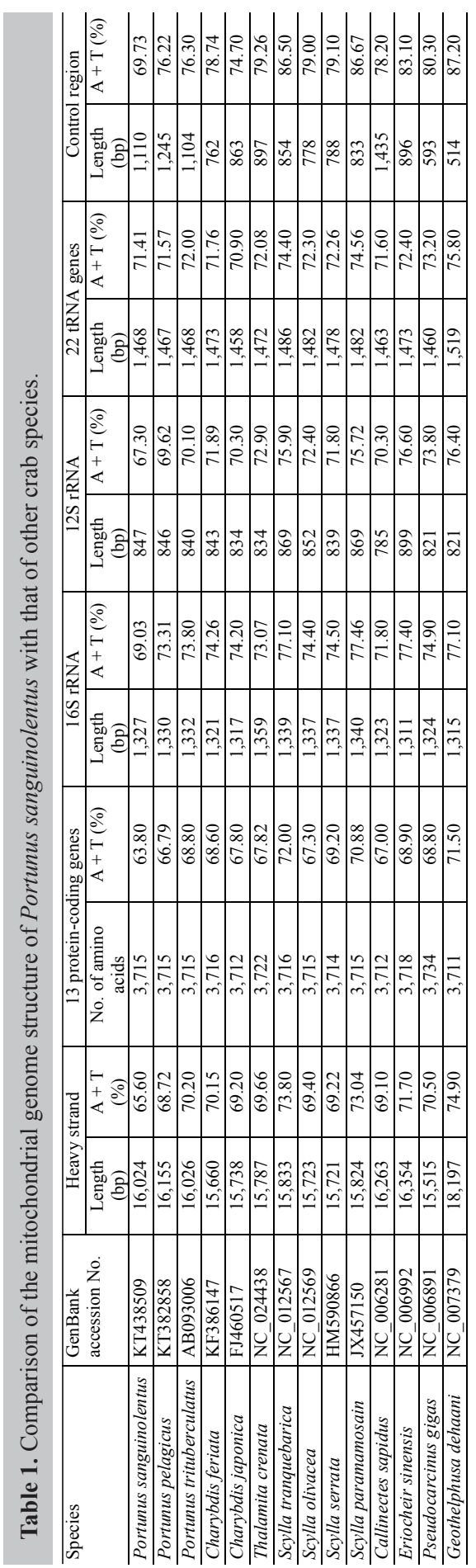

Genetics and Molecular Research 15 (3): gmr.15038580 
Table 2. Mitochondrial genome structure of Portunus sanguinolentus.

\begin{tabular}{|c|c|c|c|c|c|c|c|c|}
\hline \multirow[t]{2}{*}{ Gene } & \multicolumn{2}{|c|}{ Position } & \multirow[t]{2}{*}{ Size (bp) } & \multicolumn{3}{|c|}{ Codon } & \multirow[t]{2}{*}{ Intergenic nucleotide (bp) } & \multirow[t]{2}{*}{ Strand } \\
\hline & From & To & & Amino acid & Start & Stop & & \\
\hline $\mathrm{COI}$ & 1 & 1,534 & 1,534 & 511 & ATG & T- & 0 & $\mathrm{H}$ \\
\hline$\overline{t R N A^{\text {Leu }}(\mathrm{UUR})}$ & 1,535 & 1,599 & 65 & & & & 16 & $\mathrm{H}$ \\
\hline COII & 1,616 & 2,300 & 685 & 228 & ATG & T- & 0 & $\mathrm{H}$ \\
\hline$t R N A^{L y s}$ & 2,301 & 2,367 & 67 & & & & 0 & $\mathrm{H}$ \\
\hline$t R N A^{A s p}$ & 2,368 & 2,435 & 68 & & & & 0 & $\mathrm{H}$ \\
\hline ATP8 & 2,436 & 2,597 & 162 & 53 & ATG & TAG & -7 & $\mathrm{H}$ \\
\hline ATP6 & 2,591 & 3,268 & 678 & 225 & ATT & TAA & -1 & $\mathrm{H}$ \\
\hline COIII & 3,268 & 4,059 & 792 & 263 & ATG & TAA & -1 & $\mathrm{H}$ \\
\hline$t R N A^{G l y}$ & 4,059 & 4,122 & 64 & & & & 0 & $\mathrm{H}$ \\
\hline ND3 & 4,123 & 4,476 & 354 & 117 & ATC & TAA & 8 & $\mathrm{H}$ \\
\hline$t R N A^{A l a}$ & 4,485 & 4,549 & 65 & & & & 3 & $\mathrm{H}$ \\
\hline$t R N A^{A r g}$ & 4,553 & 4,617 & 65 & & & & 1 & $\mathrm{H}$ \\
\hline$t R N A^{A s n}$ & 4,619 & 4,684 & 66 & & & & 2 & $\mathrm{H}$ \\
\hline$t R N A^{\operatorname{Ser}(A G N)}$ & 4,687 & 4,753 & 67 & & & & 0 & $\mathrm{H}$ \\
\hline$t R N A^{\text {Glu }}$ & 4,754 & 4,820 & 67 & & & & 25 & $\mathrm{H}$ \\
\hline tRNA ${ }^{H i s}$ & 4,846 & 4,910 & 65 & & & & 1 & $\mathrm{~L}$ \\
\hline$t R N A^{\text {Phe }}$ & 4,912 & 4,976 & 65 & & & & -1 & $\mathrm{~L}$ \\
\hline ND5 & 4,976 & 6,702 & 1,727 & 575 & ATG & TA- & 17 & $\mathrm{~L}$ \\
\hline ND4 & 6,720 & 8,054 & 1,335 & 444 & ATG & TAG & -7 & $\mathrm{~L}$ \\
\hline$N D 4 L$ & 8,048 & 8,350 & 303 & 100 & ATG & TAA & 2 & $\mathrm{~L}$ \\
\hline$t R N A^{T h r}$ & 8,353 & 8,415 & 63 & & & & 0 & $\mathrm{H}$ \\
\hline$t R N A^{\text {Pro }}$ & 8,416 & 8,483 & 68 & & & & 2 & $\mathrm{~L}$ \\
\hline ND6 & 8,486 & 8,992 & 507 & 168 & ATG & TAA & -1 & $\mathrm{H}$ \\
\hline$C y t b$ & 8,992 & 10,126 & 1,135 & 378 & ATG & T-- & 0 & $\mathrm{H}$ \\
\hline$t R N A^{\operatorname{Ser}(U C N)}$ & 10,127 & 10,193 & 67 & & & & 34 & $\mathrm{H}$ \\
\hline ND1 & 10,228 & 11,184 & 957 & 318 & ATT & TAA & 5 & $\mathrm{~L}$ \\
\hline tRNA $A^{\operatorname{Leu}(C U N)}$ & 11,190 & 11,258 & 68 & & & & 1 & $\mathrm{~L}$ \\
\hline $16 S r R N A$ & 11,260 & 12,586 & 1,327 & & & & 0 & $\mathrm{~L}$ \\
\hline tRNA & 12,587 & 12,660 & 74 & & & & 0 & $\mathrm{~L}$ \\
\hline $12 S r R N A$ & 12,661 & 13,507 & 847 & & & & 0 & $\mathrm{~L}$ \\
\hline Control region & 13,508 & 14,617 & 1,110 & & & & 0 & \\
\hline tRNA & 14,618 & 14,684 & 67 & & & & -3 & $\mathrm{H}$ \\
\hline$t R N A^{G l n}$ & 14,682 & 14,750 & 69 & & & & 1 & $\mathrm{~L}$ \\
\hline$t R N A^{M e t}$ & 14,752 & 14,821 & 70 & & & & 0 & $\mathrm{H}$ \\
\hline ND2 & 14,822 & 15,829 & 1,008 & 335 & GTG & TAG & -2 & $\mathrm{H}$ \\
\hline$t R N A^{T r p}$ & 15,828 & 15,895 & 68 & & & & -1 & $\mathrm{H}$ \\
\hline$t R N A^{C y s}$ & 15,895 & 15,958 & 64 & & & & 0 & $\mathrm{~L}$ \\
\hline$\overline{t R N A}^{T y r}$ & 15,959 & 16,024 & 66 & & & & 0 & $\mathrm{~L}$ \\
\hline
\end{tabular}

\section{tRNA and rRNA genes}

A total of 22 tRNA genes were identified in the mitochondrial genome of $P$. sanguinolentus, with lengths ranging from 63 to $74 \mathrm{bp}$. The total length of tRNAs was $1468 \mathrm{bp}$, which is equal to that of $P$. trituberculatus, larger than those of $C$. japonica and Pseudocarcinus gigas, but smaller than those of $G$. dehaani and $S$. tranquebarica. In the closely related crab species $C$. japonica and $S$. paramamosain, 21 tRNAs can fold into a cloverleaf secondary structure, but one $\left[t R N A^{S e r}(A G N)\right]$ cannot form this structure because it lacks dihydrouracil (DHU) arms (Liu and Cui, 2010; Ma et al., 2013). In P. sanguinolentus, all of the tRNAs were capable of folding into a typical cloverleaf secondary structure (Figure 2). The same phenomenon has also been reported in C. feriata (Ma et al., 2015a). Of the 22 tRNAs, 14 were located on the $\mathrm{H}$-strand and 8 on the L-strand. All of the tRNA genes had a common length of $7 \mathrm{bp}$ for the aminoacyl stem and an invariable length of $7 \mathrm{bp}$ for the anticodon loop. Variable tRNA nucleotide lengths were found at the DHU, TYC, and anticodon arms. 
Table 3. Base composition of different regions of the mitochondrial genome of Portunus sanguinolentus.

\begin{tabular}{|c|c|c|c|c|c|}
\hline \multirow[t]{2}{*}{ Region } & \multicolumn{4}{|c|}{ Base composition (\%) } & \multirow[t]{2}{*}{$\mathrm{A}+\mathrm{T}$ content $(\%)$} \\
\hline & $\mathrm{A}$ & $\mathrm{G}$ & $\mathrm{T}$ & $\mathrm{C}$ & \\
\hline \multicolumn{6}{|l|}{ Protein-coding genes } \\
\hline $\mathrm{COI}$ & 24.25 & 17.47 & 35.59 & 22.69 & 59.84 \\
\hline COII & 27.45 & 15.47 & 33.58 & 23.50 & 61.02 \\
\hline ATP8 & 27.16 & 12.35 & 41.98 & 18.52 & 69.14 \\
\hline ATP6 & 27.73 & 12.54 & 36.43 & 23.30 & 64.16 \\
\hline COIII & 26.01 & 15.28 & 34.85 & 23.86 & 60.86 \\
\hline ND3 & 24.86 & 14.41 & 37.01 & 23.73 & 61.86 \\
\hline ND5 & 37.46 & 12.33 & 28.89 & 21.31 & 66.36 \\
\hline ND4 & 39.85 & 11.69 & 26.44 & 22.02 & 66.29 \\
\hline$N D 4 L$ & 42.24 & 10.23 & 23.10 & 24.42 & 65.35 \\
\hline ND6 & 23.87 & 10.85 & 41.42 & 23.87 & 65.29 \\
\hline$C y t b$ & 25.55 & 14.36 & 36.12 & 23.96 & 61.67 \\
\hline NDI & 40.44 & 12.33 & 26.65 & 20.59 & 67.08 \\
\hline$N D 2$ & 24.01 & 10.71 & 40.08 & 25.20 & 64.09 \\
\hline \multicolumn{6}{|l|}{ tRNA genes } \\
\hline$t R N A^{\text {Leu }(U U R)}$ & 35.38 & 20.00 & 30.77 & 13.85 & 66.15 \\
\hline$t R N A^{L y s}$ & 28.36 & 20.90 & 31.34 & 19.40 & 59.70 \\
\hline$t R N A^{A s p}$ & 38.24 & 10.29 & 47.06 & 4.41 & 85.29 \\
\hline$t R N A^{G l y}$ & 42.19 & 10.94 & 37.50 & 9.38 & 79.69 \\
\hline$t R N A^{A l a}$ & 33.85 & 18.46 & 35.38 & 12.31 & 69.23 \\
\hline$t R N A^{A r g}$ & 32.31 & 13.85 & 32.31 & 21.54 & 64.62 \\
\hline$t R N A^{A s n}$ & 36.36 & 16.67 & 34.85 & 12.12 & 71.21 \\
\hline$t R N A^{\operatorname{Ser}(A G N)}$ & 31.34 & 14.93 & 40.30 & 13.43 & 71.64 \\
\hline$t R N A^{\text {Glu }}$ & 29.85 & 13.43 & 43.28 & 13.43 & 73.13 \\
\hline tRNA $A^{\text {His }}$ & 41.54 & 7.69 & 30.77 & 20.00 & 72.31 \\
\hline tRNA ${ }^{\text {Phe }}$ & 27.69 & 10.77 & 38.46 & 23.08 & 66.15 \\
\hline$t R N A^{T h r}$ & 38.10 & 9.52 & 41.27 & 11.11 & 79.37 \\
\hline$t R N A^{\text {Pro }}$ & 38.24 & 8.82 & 35.29 & 17.65 & 73.53 \\
\hline$t R N A^{\operatorname{Ser}(U C N)}$ & 41.79 & 13.43 & 38.81 & 5.97 & 80.60 \\
\hline$t R N A^{\text {Leu }(C U N)}$ & 37.68 & 8.70 & 37.68 & 15.94 & 75.36 \\
\hline$t R N A^{V a l}$ & 29.73 & 13.51 & 37.84 & 18.92 & 67.57 \\
\hline tRNA $A^{\text {Ile }}$ & 35.82 & 16.42 & 38.81 & 8.96 & 74.63 \\
\hline$t R N A^{G l n}$ & 33.33 & 10.14 & 31.88 & 24.64 & 65.22 \\
\hline$t R N A^{\text {Met }}$ & 35.71 & 12.86 & 32.86 & 18.57 & 68.57 \\
\hline$t R N A^{T r p}$ & 45.59 & 10.29 & 30.88 & 13.24 & 76.47 \\
\hline$t R N A^{C y s}$ & 31.25 & 14.06 & 34.38 & 20.31 & 65.62 \\
\hline$t R N A^{T y r}$ & 30.30 & 12.12 & 34.85 & 22.73 & 65.15 \\
\hline \multicolumn{6}{|l|}{ rRNA genes } \\
\hline $16 S r R N A$ & 33.08 & 12.06 & 35.95 & 18.91 & 69.03 \\
\hline $12 S r R N A$ & 32.59 & 11.69 & 34.71 & 21.02 & 67.30 \\
\hline Control region & 33.69 & 10.45 & 36.04 & 19.82 & 69.73 \\
\hline Overall for protein-coding genes & 30.71 & 13.37 & 33.09 & 22.81 & 63.80 \\
\hline Overall for tRNA genes & 35.19 & 13.07 & 36.22 & 15.52 & 71.41 \\
\hline Overall for rRNA genes & 32.89 & 11.91 & 35.46 & 19.73 & 68.35 \\
\hline Overall for the genome & 31.59 & 12.91 & 34.01 & 21.50 & 65.60 \\
\hline
\end{tabular}

tRNA, transfer RNA; rRNA, ribosomal RNA.

All 22 tRNA genes had the common anticodons of Decapod mitochondrial genomes, except that $t R N A^{L y s}$ and $t R N A^{\operatorname{Ser}(A G N)}$ had the anticodons TTT and TCT rather than CTT and GCT, respectively. Thirteen unmatched base pairs were observed in the 22 tRNA genes, which is higher than those detected in tRNAs from C. feriata (Ma et al., 2015a). The base composition of the 22 tRNA genes was $35.19 \%$ for $A, 13.07 \%$ for $\mathrm{G}, 36.22 \%$ for $\mathrm{T}$, and $15.52 \%$ for C (Table 3 ). The overall A + T content of the tRNAs was $71.41 \%$, with the highest content $(85.29 \%)$ in $t R N A^{A s p}$ and the lowest $(59.70 \%)$ in $t R N A^{L y s}$.

Genetics and Molecular Research 15 (3): gmr.15038580 


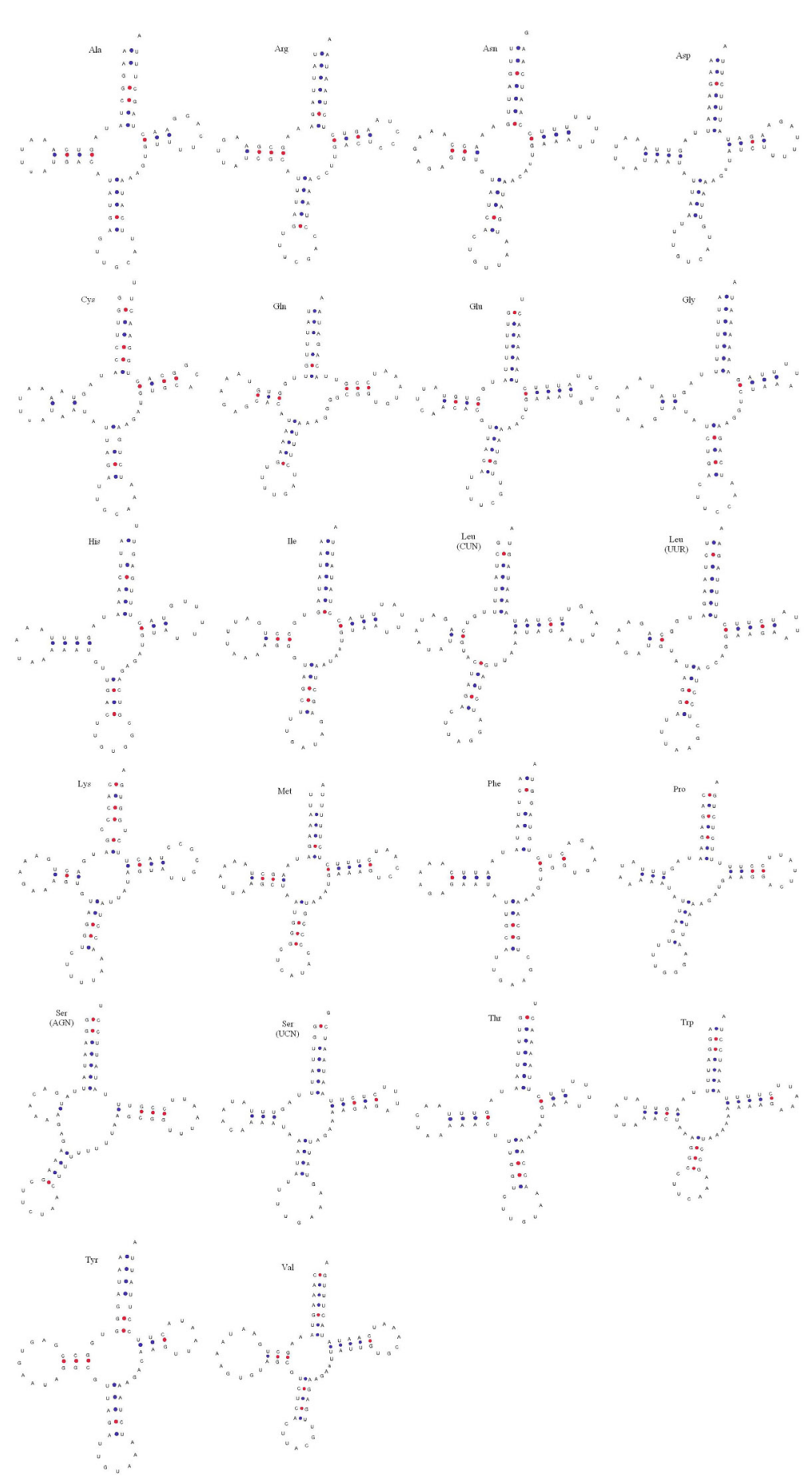

Figure 2. Predicted cloverleaf secondary structures of 22 transfer RNAs in the mitochondrial genome of Portunus sanguinolentus.

Genetics and Molecular Research 15 (3): gmr.15038580 
16S rRNA and $12 S$ rRNA were 1327 and 847 bp long, respectively, and their $\mathrm{A}+\mathrm{T}$ contents were 69.03 and $67.30 \%$, respectively. Both of them were encoded on the L-strand and were separated by $t R N A^{V a l}$, and were co-located between $t R N A^{\operatorname{Leu}(C U N)}$ and the control region.

\section{Putative control region}

The largest non-coding region was $1110 \mathrm{bp}$ long, and was predicted to be the putative control region. This non-coding region was located between $12 S r R N A$ and $t R N A^{I l e}$, which is identical to that found in other reported crab species, such as $S$. paramamosain and C. feriata. The base composition of the control region was $33.69 \%$ for $\mathrm{A}, 10.45 \%$ for $\mathrm{G}, 36.04 \%$ for $\mathrm{T}$, and $19.82 \%$ for $\mathrm{C}$. The $\mathrm{A}+\mathrm{T}$ content of the control region was high (69.73\%), but lower than that observed in most crab species, in which the $\mathrm{A}+\mathrm{T}$ content of the control region is higher than that of any other region of the mitochondrial genome. The high $\mathrm{A}+\mathrm{T}$ content is probably due to the existence of $\mathrm{A} / \mathrm{T}$ repeated motifs. In this study, TA and AT repeats were the most abundant motifs. The microsatellite repeat sequences $(\mathrm{AT})_{6},(\mathrm{TA})_{4},(\mathrm{TA})_{3},(\mathrm{AT})_{3}$, and $(\mathrm{TA})_{22}$ were also detected. Microsatellite sequences have also been found in the control region of the mitochondrial genomes of C. feriata and Nymphes myrmeleonides (Yan et al., 2014; Ma et al., 2015a).

\section{Phylogenetic relationships}

In order to elucidate the molecular phylogeny of representative species in the family Portunidae, we constructed a phylogenetic tree using 23 species within the Decapoda. The tree topologies (Figure 3) revealed that $P$. sanguinolentus first grouped together with its sister species $P$. trituberculatus and $P$. pelagicus, and then formed a monophyletic group with $C$. sapidus. The molecular evidence presented here supports the species' traditional taxonomic status. The tree also showed that the genus Charybdis is genetically closest to the genus Thalamita; species within these two genera clustered as a monophyletic group. Furthermore, the genera Charybdis and Thalamita have a very close relationship with crab species in the subfamily Portuninae. Previous studies have shown that Charybdis is closer to the subfamily Portuninae than to the subfamily Thalamitinae (Liu and Cui, 2010; Ma et al., 2015a). Our results confirm that Thalamita is closest to Charybdis, and both should be classified into the subfamily Portuninae rather than the subfamily Thalamitinae.

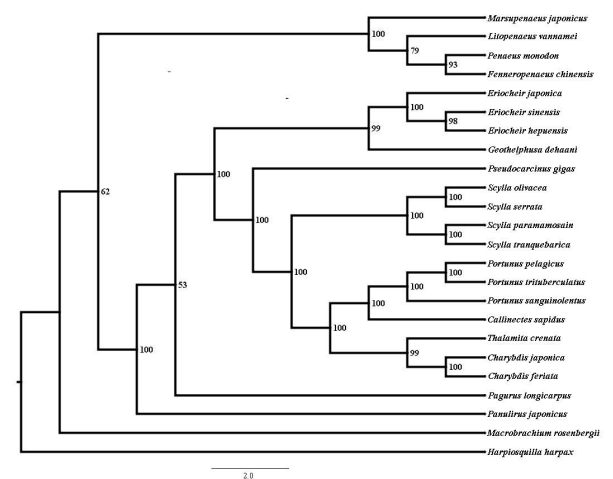

Figure 3. Molecular phylogenetic relationships between 23 species of Decapoda based on 12 protein-coding genes of the mitochondrial genome.

Genetics and Molecular Research 15 (3): gmr.15038580 


\section{CONCLUSIONS}

This study investigated the complete mitochondrial genome of the three-spot swimming crab (P. sanguinolentus), which contained a typical set of 37 genes and a putative control region. Molecular phylogenomic analysis based on 12 protein-coding genes demonstrated that $P$. sanguinolentus is genetically closest to its sister species, $P$. trituberculatus and $P$. pelagicus, and we suggest classifying the genera Charybdis and Thalamita into the subfamily Portuninae rather than the subfamily Thalamitinae. Our results will be useful for studies on phylogenetic relationships, population genetic diversity, and the conservation genetics of $P$. sanguinolentus and related crab species.

\section{Conflicts of interest}

The authors declare no conflict of interest.

\section{ACKNOWLEDGMENTS}

Research supported by the National Program for Support of Top-Notch Young Professionals, and the National Basic Research Special Foundation of China (\#2013FY110700).

\section{REFERENCES}

Campbell GR and Fielder DR (1986). Size at sexual maturity and occurrence of ovigerous females in three species of commercially exploited portunid crabs in S.E. Queensland. P. Roy. Soc. Queensland 97: 79-87.

Dinakaran GK and Soundarapandian P (2009). Mating behavior and broodstock development of commercially important blue swimming crab, Portunus sanguinolentus (Herbst). Indian J. Sci. Technol. 2: 71-75.

Guo Y, Wang Z, Liu C and Liu Y (2008). Sequencing and analysis of the complete mitochondrial DNA of Russell's snapper (L. russellii). Prog. Nat. Sci. 18: 1233-1238. http://dx.doi.org/10.1016/j.pnsc.2008.07.001

Korkmaz EM, Budak M, Ördek MN and Başıbüyük HH (2016). The complete mitogenomes of Calameuta filiformis (Eversmann, 1847) and Calameuta idolon (Rossi, 1794) (Hymenoptera: Cephidae): The remarkable features of the elongated A+T rich region in Cephini. Gene 576: 404-411.http://dx.doi.org/10.1016/j.gene.2015.10.050

Kumar S, Nei M, Dudley J and Tamura K (2008). MEGA: a biologist-centric software for evolutionary analysis of DNA and protein sequences. Brief. Bioinform. 9: 299-306. http://dx.doi.org/10.1093/bib/bbn017

Lee HH and Hsu CC (2003). Population biology of the swimming crab Portunus sanguinolentus in the waters off northern Taiwan. J. Crustac. Biol. 23: 691-699. http://dx.doi.org/10.1651/C-2358

Liu Y and Cui Z (2010). Complete mitochondrial genome of the Asian paddle crab Charybdis japonica (Crustacea: Decapoda: Portunidae): gene rearrangement of the marine brachyurans and phylogenetic considerations of the decapods. Mol. Biol. Rep. 37: 2559-2569. http://dx.doi.org/10.1007/s11033-009-9773-2

Lohse M, Drechsel O and Bock R (2007). OrganellarGenomeDRAW (OGDRAW): a tool for the easy generation of high-quality custom graphical maps of plastid and mitochondrial genomes. Curr. Genet. 52: 267-274. http://dx.doi. org/10.1007/s00294-007-0161-y

Lowe TM and Eddy SR (1997). tRNAscan-SE: a program for improved detection of transfer RNA genes in genomic sequence. Nucleic Acids Res. 25: 955-964. http://dx.doi.org/10.1093/nar/25.5.0955

Ma H, Ma C, Li X, Xu Z, et al. (2013). The complete mitochondrial genome sequence and gene organization of the mud crab (Scylla paramamosain) with phylogenetic consideration. Gene 519: 120-127. http://dx.doi.org/10.1016/j. gene.2013.01.028

Ma H, Ma C, Li C, Lu J, et al. (2015a). First mitochondrial genome for the red crab (Charybdis feriata) with implication of phylogenomics and population genetics. Sci. Rep. 5: 11524.http://dx.doi.org/10.1038/srep11524

Ma H, Ma C, Zhang H, Zhang X, et al. (2015b). Characterization of the complete mitochondrial genome and phylogenetic relationship of Caranx tille (Perciformes: Carangidae). Mitochondrial DNA 1-2 10.3109/19401736.2015.1106510.

Genetics and Molecular Research 15 (3): gmr.15038580 
Ma HY, Yang JF, Su PZ and Chen SL (2009). Genetic analysis of gynogenetic and common populations of Verasper moseri using SSR markers. Wuhan Univ. J. Nat. Sci. 14: 267-273. http://dx.doi.org/10.1007/s11859-009-0315-5

Mantelatto FL, Robles R and Felder DL (2007). Molecular phylogeny of the western Atlantic species of the genus Portunus (Crustacea, Brachyura, Portunidae). Zool. J. Linn. Soc. 150: 211-220. http://dx.doi.org/10.1111/j.1096$\underline{3642.2007 .00298 . x}$

Meng X, Jia F, Zhang X, Liu P, et al. (2016a). Complete sequence and characterization of mitochondrial genome in the swimming crab Portunus sanguinolentus (Herbst, 1783) (Decapoda, Brachyura, Portunidae). Mitochondrial DNA 27: 3052-3053.

Meng XL, Jia FL, Liu P and Li J (2016b). The complete mitogenome of blue swimming crab Portunus pelagicus Linnaeus, 1766 (Crustacea: Decapoda: Portunidae). Mitochondrial DNA 27: 2789-2790.

Mu X, Liu Y, Lai M, Song H, et al. (2015). Characterization of the Macropodus opercularis complete mitochondrial genome and family Channidae taxonomy using Illumina-based de novo transcriptome sequencing. Gene 559: 189195.http://dx.doi.org/10.1016/j.gene.2015.01.056

Ojala D, Montoya J and Attardi G (1981). tRNA punctuation model of RNA processing in human mitochondria. Nature 290: 470-474. http://dx.doi.org/10.1038/290470a0

Rasheed S and Mustaquim J (2010). Size at sexual maturity, breeding season and fecundity of three-spot swimming crab Portunus sanguinolentus (Herbst, 1783) (Decapoda, Brachyura, Portunidae) occurring in the coastal waters of Karachi, Pakistan. Fish. Res. 103: 56-62. http://dx.doi.org/10.1016/j.fishres.2010.02.002

Sahoo PK, Goel C, Kumar R, Dhama N, et al. (2015). The complete mitochondrial genome of threatened chocolate mahseer (Neolissochilus hexagonolepis) and its phylogeny. Gene 570: 299-303.http://dx.doi.org/10.1016/j.gene.2015.07.024

Shen X, Ren J, Cui Z, Sha Z, et al. (2007). The complete mitochondrial genomes of two common shrimps (Litopenaeus vannamei and Fenneropenaeus chinensis) and their phylogenomic considerations. Gene 403: 98-109. http://dx.doi. org/10.1016/j.gene.2007.06.021

Stamatakis A, Hoover P and Rougemont J (2008). A rapid bootstrap algorithm for the RAxML Web servers. Syst. Biol. 57: 758-771. http://dx.doi.org/10.1080/10635150802429642

Stephenson W and Campbell B (1959). The Australian portunids (Crustacea: Portunidae). III. The genus Portunus. Aust. J. Mar. Freshwater Res. 10: 84-124. http://dx.doi.org/10.1071/MF9590084

Sumpton WD, Smith GS and Potter MA (1989). Notes on the biology of the Portunid crab, Portunus sanguinolentus (Herbst), in subtropical Queensland waters. Aust. J. Mar. Freshwater Res. 40: 711-717. http://dx.doi.org/10.1071/ MF9890711

Yamauchi MM, Miya MU and Nishida M (2003). Complete mitochondrial DNA sequence of the swimming crab, Portunus trituberculatus (Crustacea: Decapoda: Brachyura). Gene 311: 129-135. http://dx.doi.org/10.1016/S0378$\underline{1119(03) 00582-1}$

Yan Y, Wang Y, Liu X, Winterton SL, et al. (2014). The first mitochondrial genomes of antlion (Neuroptera: Myrmeleontidae) and split-footed lacewing (Neuroptera: Nymphidae), with phylogenetic implications of Myrmeleontiformia. Int. J. Biol. Sci. 10: 895-908. http://dx.doi.org/10.7150/ijbs.9454

Yang CP, Li HX, Li L, Xu J, et al. (2014). Population structure, morphometric analysis and reproductive biology of Portunus sanguinolentus (Herbst, 1783) (Decapoda: Brachyura: Portunidae) in Honghai Bay, South China Sea. J. Crustac. Biol. 34: 722-730. http://dx.doi.org/10.1163/1937240X-00002273

Yu JN, Azuma N and Abe S (2012). Genetic differentiation between collections of hatchery and wild masu salmon (Oncorhynchus masou) inferred from mitochondrial and microsatellite DNA analysis. Environ. Biol. Fishes 94: 259271. http://dx.doi.org/10.1007/s10641-011-9869-0

Genetics and Molecular Research 15 (3): gmr.15038580 